\title{
The Impact Of A 'Demand-Driven’ Higher Education Policy In Australia
}

Anthony Stokes, Australian Catholic University, Australia

Sarah Wright, Australian Catholic University, Australia

\begin{abstract}
In 2012, the Australian government introduced a 'demand-driven' entitlement system for domestic higher education students in which recognised higher education providers are free to enrol as many eligible students as they wish in eligible higher education courses and receive corresponding government subsidies for those students. This paper examines the impact that already has occurred as a result of this decision and the likely long-term effects that this will have on higher education in Australia.
\end{abstract}

Keywords: Higher Education Policy; Demand-Driven; Deregulation

\section{INTRODUCTION}

$\mathscr{I}$ n March 2008, the Australian government announced a major review to consider the challenges and issues facing higher education in Australia. This was to become known as the Bradley Review. In May 2009, the government released its initial response to this review in Transforming Australia's Higher Education System. This response adopted many of the Bradley Review's recommendations. The Bradley Review recommended, and Transforming Australia's Higher Education System supported, a more deregulated higher education system. Transforming Australia's Higher Education System supported the Bradley Review's proposal that the Australian government should introduce a 'demand-driven' entitlement system for domestic higher education students in which recognised providers would be free to enrol as many eligible students as they wish in eligible higher education courses and would receive corresponding government subsidies for those students. The 'demanddriven' concept, in this case, is not the traditional economics concept, but rather one where government funding is allocated based on the number of students that wish to study a course in conjunction with the disciplines and courses where a university allocates the most student admissions. An increase in the number of students in a course and, as a result, an increase in government funding in a course can generally be achieved by lowering university entry scores. In 2012, the 'demand-driven' higher education policy was implemented by the Australian government. This paper examines the impact that already has occurred as a result of this policy and the likely long-term effects that this will have on higher education in Australia.

\section{AN OVERVIEW OF THE BRADLEY REVIEW}

In 2008, the Minister for Education, Julia Gillard, initiated a review of Australian higher education to be chaired by Professor Bradley. The Bradley Review, and its subsequent report that was presented at the end of 2008, put forth a number of recommendations that potentially would change the face of higher education in Australia in future decades.

Two of the main recommendations of the Bradley Review (2008 xiii- xvii) were:

1. National targets for attainment of degree qualifications and for participation of low socio-economic status students will be set and institution-specific targets for participation and performance will be established and monitored.

(C) 2012 The Clute Institute http://www.cluteinstitute.com/ 
The target proposed for higher education was that 40 percent of 25 to 34 -year-olds would have attained at least a bachelor-level qualification by 2020 . The Review Committee considered that this would be a difficult target to achieve as the current attainment level was only 29 percent. Another important target that was set was one to ensure that those from disadvantaged backgrounds 'aspire to and are able to participate in higher education'. The Review recommended that by 2020, 20 percent of undergraduate enrolments in higher education should be students from low socio-economic backgrounds.

2. All qualified students would receive an entitlement for a Commonwealth subsidised place of admission at university. In addition, students would have a choice of where to study at recognised institutions and the institutions would have freedom to enrol as many students as they wished.

The Bradley Report recommended a more deregulated higher education system. It proposed that the government should introduce a 'demand-driven' entitlement system for domestic higher education students in which recognised providers are free to enrol as many eligible students as they wish in eligible higher education courses and receive corresponding government subsidies for those students. The arrangements would initially apply to undergraduate courses but then be extended to post-graduate coursework-level courses subject to further work on the balance of public and private benefits at that level of study. There would be no time or dollar limit on the value of the entitlement. Eligible higher education providers would be allowed to set their own entry standards and determine which, and how many, students to enrol. In addition, universities would be allowed to change the mix of student load by discipline cluster in response to demand. This was seen to be consistent with the need to broaden the base of higher education qualifications in the population and the need for skills upgrading over the individual's life cycle. Such a system would allow institutions the flexibility to decide the courses that they would offer and the number of students they would admit.

\section{THE IMPACT OF THE 'DEMAND-DRIVEN' MODEL}

While many of the recommendations of the Bradley Review seemed positive, including the opening up of access to students to higher education and increasing the quality of higher education, the outcomes may not be all that is desired. With the expected implementation of the 'demand-driven' model in 2012, a number of higher education providers started taking steps to maximise the benefits to their institutions from a more deregulated higher education system. This included increasing enrolments in their courses as early as 2009 with the aim of achieving much larger financial support with the introduction of the 'demand-driven' model in 2012. While the aim of the 'demand-driven' policy was to increase student numbers and have student choice determine the places available in universities, the reality for some institutions was to expand their student numbers and funding as much as possible and at any cost. There is already evidence suggesting that the higher education market is moving in ways that may not be in the best interest of the students or society as a whole. The following sections examine some of the effects of a movement to a 'demand-driven' deregulated higher education system.

\section{Is A Goal of 40 Percent of All 25 to 34-year Olds Attaining A Bachelor Degree or Above by 2020 Realistic?}

The Bradley Report (2008) claims that immediate action is necessary in order to address the shortfall in the number of qualified people in Australia over the next coming years. As a result, the Australian government has recommended that at least 40 percent of all 25 to 34-year olds attain a bachelor degree or above by 2020 . While this may be considered a desirable goal, one has to question whether this goal is realistic and, secondly, if it is achieved, the impact it could have on the economic benefits of a university degree, and consequently the number of individuals studying at university in the future. So far, the government has encouraged universities to enrol a greater number of students. However, increasing the number of students enrolled in university does not mean that they will all graduate. A serious shortcoming of this recommendation is that it focuses on the completion of a degree (attainment). It is likely that many more students will be enrolled and subsequently funded by the government (and the students themselves) than those who complete the degree. The goal does not consider the attrition rate or the quality associated with the various courses undertaken by the students. Studies, such as McMillan (2005), have shown that by enrolling more students, and consequently lowering the standards of entry into university, the attrition rate of students increases. For instance, McMillan (2005) found that the attrition rate for students with a university entry score of 90 or more was five percent, whereas for those with an entry score of less than 70, there was an 
attrition rate of 23 percent. This would suggest that by increasing enrolments, not only will the quality of education and graduates decline, but there is also no guarantee that the students will complete the course.

There are already signs that the movement to a demand-driven funding model based on the numbers of enrolled students has led to a larger enrolment of students in some courses and universities and arguably a lowering of educational standards. There is evidence of universities increasing student enrolment by over 30 percent in excess of their government funding quota in an attempt to gain a greater market share and higher levels of education funding from both students and the government. The Australian Catholic University is leading the over-enrolment targets with over-enrolments of 41.2 percent in 2011, with 75 percent of these unfunded by the government (Lane, 2011). Macquarie University had the second highest level of over-enrolments in Australia at 29.4 percent. Six of the eight universities in Australia, with over-enrolments in excess of 20 percent, are in New South Wales. One of the consequences of attempting to enrol more students has been a reduction in the admission scores at many of these universities. Table 1 shows how the ATAR $^{1}$ entry scores have been reduced at a number of universities in NSW notably at the Australian Catholic University, University of Western Sydney, Newcastle, and Wollongong - since 2007 to achieve these aggressive targets. The lower entry scores reflect, overall, a lower standard of student entering the degrees. While there has been little effect on the high ATAR entry score universities, such as the University of Sydney and University of NSW, there have been reductions in most of the middle range and lower ATAR-level universities. The largest over-enroller - Australian Catholic University - has lowered the entry scores by eight percentage points for an Arts degree and 13.7 percentage points for a Business/Commerce degree. There is already evidence that an increased proportion of students are failing units in at least some of the universities that have lowered their entry scores. These reductions in entry requirements may lead to some universities lowering their standards to maintain the retention and graduate rates of these lower-ability students. This will not increase the quality of university courses in Australia, but rather lower the quality.

Table 1: Australian Tertiary Admissions Rank (ATAR) - 2007 and 2011 - and Over-enrolment Levels in 2011

\begin{tabular}{|c|c|c|c|}
\hline University and Course & $\begin{array}{c}\text { 2007 ATAR } \\
\text { (Equivalent) }^{\mathrm{a}}\end{array}$ & 2011 ATAR & $\begin{array}{c}\text { Percentage of Over- } \\
\text { enrolments (2011) }\end{array}$ \\
\hline University of NSW & & & 23.0 \\
\hline Arts & 81.65 & 80.00 & \\
\hline Business/Commerce & 95.50 & 96.70 & \\
\hline University of Sydney & & & 7.6 \\
\hline Arts & 84.40 & 84.00 & \\
\hline Business/Commerce & 95.35 & 95.50 & \\
\hline Macquarie University & & & 29.6 \\
\hline Arts & 81.65 & 75.05 & \\
\hline Business/Commerce & 84.55 & 83.60 & \\
\hline University of Wollongong (Wollongong) & & & 24.5 \\
\hline Arts & 79.85 & 75.00 & \\
\hline Business/Commerce & 81.65 & 75.00 & \\
\hline University of Western Sydney & & & 24.5 \\
\hline Arts & 72.60 & 70.00 & \\
\hline Business/Commerce & 73.55 & 65.10 & \\
\hline University of Newcastle (Callaghan) & & & 22.0 \\
\hline Arts & 67.35 & 60.00 & \\
\hline Business/Commerce & 67.35 & 60.00 & \\
\hline Australian Catholic University (Sydney) & & & 41.2 \\
\hline Arts & 68.05 & 60.05 & \\
\hline Business/Commerce & 72.70 & 59.00 & \\
\hline
\end{tabular}

${ }^{a}$ In 2007, universities in NSW applied a Universities Admission Index (UAI) for university entry. For 2007, the UAI has been adjusted to an equivalent ATAR, using the Universities Admission Centre conversion table. Source: UAC (2007, 2011) and Lane (2011)

The impact of lower entry scores for universities has been magnified by the use of direct entries to courses. Direct entries are students who have been accepted into university by other criteria to an ATAR score. Some

\footnotetext{
${ }^{1}$ Australian Tertiary Admission Rank (ATAR) is the Australian university entry score with a maximum of 100. 
universities are expanding their student numbers by increasing the number of direct entry candidates by lowering the requirements for direct entry. Direct entry candidates do not have any form of comparable entry score and, as a result, there is no transparent way of measuring changes to entry requirements. There is, however, anecdotal evidence that some universities are accepting students into courses with much lower standards compared to the ATAR achievement levels. While a university ATAR score generally requires at least 12 years of schooling in Australia, students are being accepted under the direct entry provisions with 10 or less years of schooling. In one case, a student was accepted into university with only nine years of schooling in Sudan, followed by a one-year university preparation program in a Technical and Further Education college (TAFE).

The issue of university completion rates, rather than entry rates, is also very important. The Bradley Review states that while the proportion of 25 to 34-year old students with a bachelor degree had increased significantly, from 16 percent in 1996 to 29 percent in 2006, Australia's position among OECD nations had fallen from $6^{\text {th }}$ to $9^{\text {th }}$ place with countries such as Sweden and New Zealand improving at a faster rate. However, one has to question whether the benefits of attending university are really improving for the university students in Sweden and New Zealand and should the Australian government set a target of 40 percent to keep up with these nations. In regards to completion rates, Australia had one of the lowest dropout rates, out of all OECD nations, at 20 percent, whereas nations such as New Zealand and Sweden had much higher dropout rates at 43 percent and 51 percent, respectively. It is important to note that while New Zealand and Sweden have much easier access to university than currently exists in Australia, they also have higher failure rates for their students. The consequences of this have been higher costs to students and the governments in both nations without the attainment of university qualifications. This could also be an outcome of increasing the entry rates of students into Australian universities under this model.

\section{What Are the Possible Consequences of Having 40 Percent of All 24 to 34-year Olds Holding A Bachelor Degree or Above by 2020?}

Assuming that the Bradley target of 40 percent of all 25 to 34-year olds obtain a university degree is achieved by 2020, one has to question whether the outcome would be all that desirable. The human capital model (Becker, 1975) suggests that students will only invest in human capital if the discounted return that they expect to receive in the future is greater than the costs borne immediately. The cost of a university degree is the opportunity cost of an individual studying at university and the return is the income premium the university graduate receives as a result of their investment in higher education. The summary statistic that uses a discount rate to compare the total cost of study with the net benefits of higher education is known as the Private Rate of Return (PRR). The return on investment is only worthwhile when the Private Rate of Return is greater than the return on an alternative investment, such as the government bond rate.

Studies, such as Borland (2002), Wei (2010), and Stokes and Wright (2010), show that the PRR to a university degree in Australia has fallen over time. According to Wei (2010), the PRR for a bachelor degree is currently 15.3 percent for males and 17.3 percent for females, whereas in 1986, it was 17.5 percent and 20.3 percent, respectively. Despite the fall in the PRR to a bachelor degree, studies show that the return to a university degree in Australia is significantly higher than the return in countries such as New Zealand and Sweden. According to the OECD (2010), the PRR to a bachelor degree in Australia is 9.1 percent for males and 11.3 percent for females. Meanwhile the PRR for New Zealand is 7.2 percent for males and 6.5 percent for females and for Sweden, 6.1 percent for males and 5.3 percent for females. These results suggest that the PRR is not only lower in both New Zealand and Sweden, but the PRR is lower for females than males in these countries. The likely reasons for the difference in the PRR for a bachelor degree between these countries are variations in the cost of tuition and/or the income premium. In recent decades, Australia has seen an increase in the level of student contributions toward the cost of higher education. According to the OECD (2010) Australia has the fourth highest average tuition costs for studying a bachelor degree out of all OECD nations (at US\$14,426), as shown in Table 2. The fees to study for a bachelor degree are significantly lower in New Zealand (at US\$8,509) and Sweden (at US\$4,145). This would suggest that the PRR for a bachelor degree should be lower in Australia than in New Zealand or Sweden. However, despite the high tuition fees in Australia, the PRR for a bachelor degree is higher in Australia than in both of these countries. This is largely due to the higher wage premium for obtaining a bachelor degree in Australia compared to New Zealand or Sweden. 
The compressed wage differentials in New Zealand and Sweden are arguably a result of the oversupply of university graduates in the labour market. This is further supported by the OECD (2010) findings of the highest returns for a bachelor degree (in excess of 19 percent) being in countries with shortages of skilled academic graduates, such as Poland and the Czech Republic.

These results suggest that if the supply of university graduates in Australia increases, the earnings premium will decrease, consequently reducing the PRR to a university degree and discouraging people from investing in a higher education. Furthermore, if the supply of university graduates increases, the unemployment rate is also likely to increase. The impact of a higher number of university graduates on the income premium and unemployment rate can already be seen when comparing GradStats data for the years 1977 to 2010, as shown in Figure 1 (Graduate Careers Australia, 2010). The median salary for university graduates, as a proportion of Male Average Weekly Earnings (MAWE) in 2010, was 81.4 percent for males and 78.2 percent for females (Graduate Careers Australia, 2010). This is significantly lower than in 1977 when the median salary for university graduates, as a percentage of MAWE, was 103 percent for males and 98 percent for females. GradStats data show that from 2008 to 2010, the median salary decreased 4.1 percentage points for males and 2.7 percentage points for females.

Table 2: Tuition Costs for An Individual Obtaining Tertiary Education as Part of Initial Education in Equivalent USD, Converted with PPPs for GDP - 2006

\begin{tabular}{|l|c|c|}
\hline \multicolumn{1}{|c|}{ Country } & Individual Tuition Costs & Government Contribution \\
\hline Australia & 14,426 & 43,209 \\
\hline Austria & 7,879 & 20,552 \\
\hline Belgium & 2,133 & 35,321 \\
\hline Canada & 30,820 & 10,644 \\
\hline Czech Republic & 2,317 & 51,220 \\
\hline Denmark & 1,887 & 33,779 \\
\hline Finland & 1,603 & NA \\
\hline France & $\mathrm{NA}$ & 33,206 \\
\hline Germany & 5,852 & 14,177 \\
\hline Hungary & 4,034 & 18,847 \\
\hline Italy & 6,977 & 4,619 \\
\hline Korea & 15,329 & 34,104 \\
\hline Netherlands & 12,351 & 14,504 \\
\hline New Zealand & 8,509 & 34,075 \\
\hline Norway & 1,043 & 10,791 \\
\hline Poland & 4,547 & 11,848 \\
\hline Portugal & 5,903 & 22,289 \\
\hline Spain & 7,086 & 33,959 \\
\hline Sweden & 4,149 & 9,567 \\
\hline Turkey & 1,061 & 24,919 \\
\hline United Kingdom & 13,536 & $\mathrm{NA}$ \\
\hline United States & $\mathrm{NA}$ & 23,734 \\
\hline OECD average & 7,572 & \\
\hline Source OECD & $\mathrm{n}$ & \\
\hline
\end{tabular}

Source: OECD (Education at a Glance 2010, Tables A8.2, A8.4)

Not only were median salaries decreasing in the period 2008-2010, but so were the employment rates for those who had recently graduated with bachelor degrees. In 2008, 85.5 percent of males and 80 percent of females who had recently graduated were in full-time work. By 2010, only 75.4 percent of male and 76.8 percent of female recent graduates were in full-time work.

The side effects of an over-supply of university graduates can also be seen in the differences between the income and employment rates of various occupations. In 2010, the unemployment rate for university graduates ranged from 1.6 percent for graduates of dentistry to 16.5 percent for those in the field of social science compared to a national unemployment rate for all individuals of 5.1 percent. In 2010, new graduates in disciplines, such as accounting and computing, had relatively high unemployment rates at 10.6 percent and 13.7 percent, respectively. Increasing the number of graduates in these disciplines will only add to the unemployment rate and, in the longer term, discourage capable students from undertaking university study. 


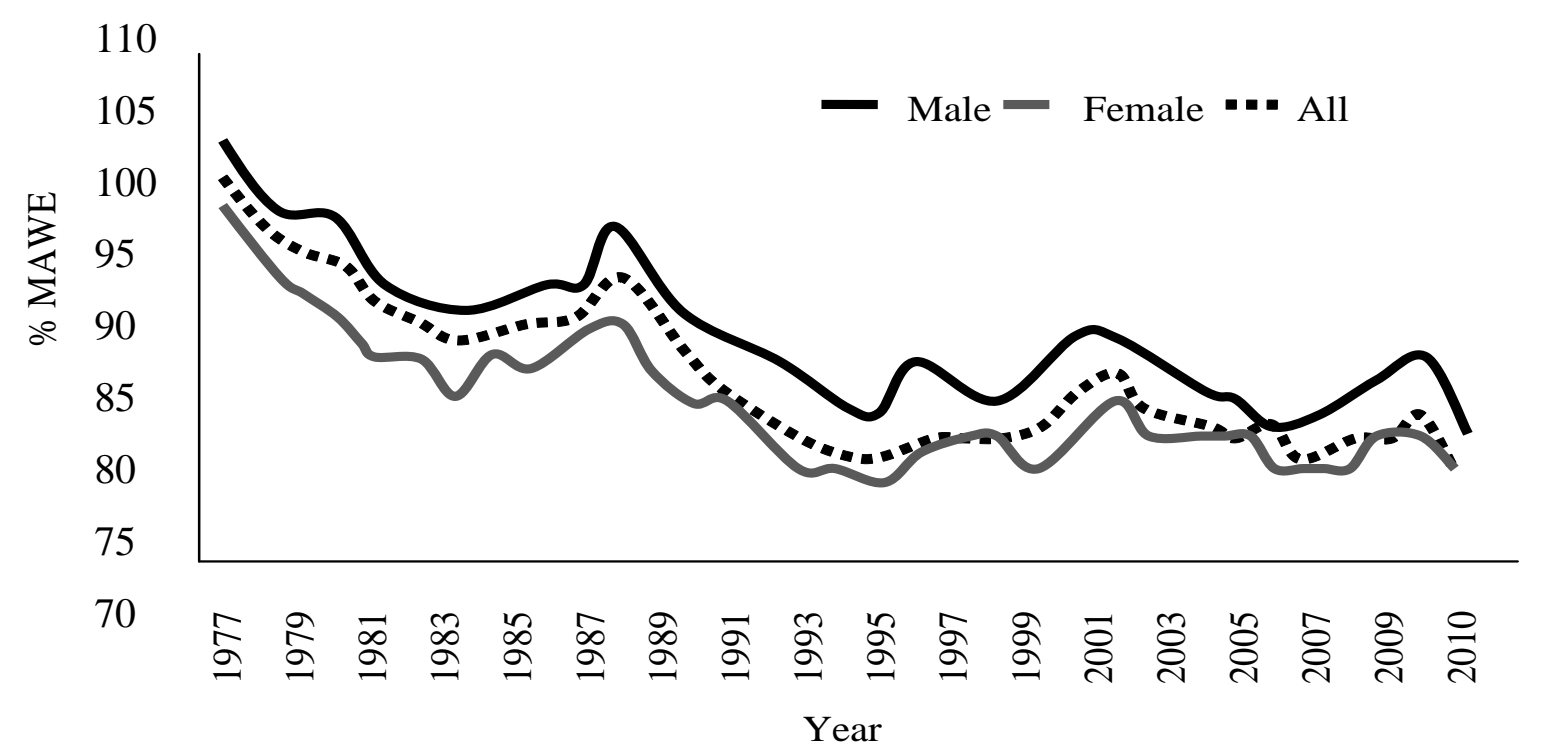

Source: Gradstats 2010

Figure 1: Male, Female and All Graduates' Median stating Salaries Relative to the Annual Rate of Full-time Male Average Weekly Earnings (MAWE) - 1977-2010

A serious weakness of most policies and decisions made in the higher education sector is that decisionmakers rely on an underlying assumption that the market for higher education is characterised by complete information and allocative efficiency. Studies, such as Wright (2008), show that the market for higher education in Australia is characterised by asymmetrical information, where students are unable to make an informed decision about which course to study and at which institution because of the lack of information available to them. Therefore, it is unlikely that increasing the numbers of students enrolling in university will reduce the skills shortage. There is a need to target the discipline areas where there are current and likely skill shortages in the future. Therefore, this government's recommendation, together with the lack of information available to students, could result in more graduates entering saturated fields, lifting the unemployment rate higher, and driving down the PRR to their degree. In countries such as New Zealand and Ireland, this led to a brain drain, where graduates sought employment in other countries. If Australia's most educated citizens leave Australia for work in other nations, this would defeat the aim of this recommendation. The Emigration 2007-2008 Report revealed Australia's largest brain drain to date. The global demand for skills and the internationalisation of the labour market led to a 6.7 percent increase in the number of people permanently leaving Australia. Nearly half of the 76,923 who left Australia permanently in 2007-08 were in skilled jobs and nearly two-thirds were between 25 and 54 years of age.

\section{THE LESSONS TO BE LEARNED FROM OVERSEAS EXPERIENCES}

In 2011, when universities in Australia were enrolling more students, four out of eight universities in New Zealand decided to restrict student access by raising their entry requirements, including setting higher cut-off scores and higher literacy standards (University World News, 2010). This move by universities was motivated by the lack of government funding for the greater number of students who enrolled because of New Zealand's recession. Although more New Zealand students will miss out on a place at university this year, other potential outcomes will include a better quality of education and a more financially viable position for universities in New Zealand.

The expansion of tertiary education in Australia could result in an aftermath similar to Hong Kong. According to a study by Lui and Suen (2005), in 1989 the Hong Kong government encouraged a large increase in the supply of university graduates to accommodate for the unexpected future demand for skilled labour. This resulted in the proportion of degree holders in Hong Kong increasing from 5.3 percent in 1981 to 16.8 percent in 
2001. However, instead of the university graduates enjoying the benefits of a university degree and a labour market with skill shortages, the earnings premium of a university graduate declined. Lui and Suen (2005) argue that there are two possible reasons for the decline in the earnings premium of a university degree - known as the crowding effect and quality effect. The crowding effect is where an increase in the supply of university graduates leads to imperfect substitutes, diminishing returns and the downgrading of the type of jobs that require a university degree. The quality effect is defined as reducing the standards of entry results in a lower quality of graduates, a lower level of productivity, and consequently lower wages. Lui and Suen (2005) argue that the crowding effect would impact upon all degree holders, whereas the quality effect only affects those graduates who enrolled into university after the expansion. Therefore, if the relative earnings of young graduates fell more sharply than older graduates, the quality effect is mostly responsible for the fall in the earnings premium. Lui and Suen (2005) found that the earnings premium of a university degree had fallen for all university graduates but the decline was more substantial among younger than older groups. This suggests that the labour market cannot respond to a large increase in the supply of university graduates without reducing their relative wage level.

\section{THE DECLINE IN STUDENT QUALITY}

The large-scale expansion of tertiary education in recent years in Australia has resulted in the fall in university entry requirements. This is supported by the fall in the ATAR cut-offs for various degrees, as shown in Table 1. In addition, there has also been a decline in the proportion of students of higher ability accepting an offer to study at university. The AVCC (2006) reports that in 2004, 96 percent of year 12 students with an entry score of 90.05+ applied for a place at university, 96 percent of those received an offer, and 83 percent had accepted their offer. By 2009, only 89 percent of year 12 students with an entry score of $90.05+$ applied for a place at university and, even though 92 percent of these students received an offer, only 78 percent accepted their offer (DEEWR, 2010). At the other end of the entry scale, the proportion of year 12 students being accepted into university with an entry score of between 50.05 and 60.00 increased. In 2004, 60 percent of year 12 students with an entry score of between 50.05 and 60.00 applied for a place at university. Of these students, 17 percent received an offer and 12 percent accepted their offer. In 2009, 60 percent of year 12 students with an entry score of between 50.05 and 60.00 applied for a place at university. Of these students, 57 percent received an offer and 47 percent accepted their offer. This suggests that the number of year 12 students with an entry score of between 50.05 and 60.00 studying at university has more than tripled in five years (AVCC, 2006 and DEEWR, 2010). In addition, the proportion of year 12 students, with an entry score less than 50 receiving and accepting an offer, has also increased. Not only are a greater proportion of lower-ability students going to university, but a larger proportion of very capable students are turning down the offer to attend university. This will have an impact not only on the quality of students entering university but also the quality of graduates. McInnis and Hartley (2002) found that there is a positive relationship between a student's university entrance score and the grade point average that they achieve at university. A continuation of this trend would most likely produce a lower quality of graduates.

\section{The Impact on the Opportunities for Students from Low Socio-economic Status Backgrounds}

One has to question what impact the changes occurring in light of the Bradley Review would have on the government's recommendation that by 2020, 20 percent of higher education enrolments at undergraduate level are from low socio-economic status backgrounds. Studies, such as James (2002) and Wright (2005), have shown that students from low socio-economic areas are more debt adverse than all other income groups, such that increases in the level of student contributions have discouraged students from low socio-economic areas from participating in higher education. Wright (2005) found that increased university fees between 1996 and 2001 reduced the proportion of low SES student commencing university in the Sydney region. Furthermore, a study by Borg (2006) that compared university and TAFE students in New South Wales showed that TAFE provided equal access to postschool education based on socio-economic groups in 2001. This suggests that students from low socio-economic backgrounds are not opposed to post-school education but rather are deterred from the higher cost of university education. The Borg study did show, however, that when TAFE fees were increased in 2004, there was a considerable decline in TAFE enrolments.

Not only should high achieving students from low socio-economic areas have access to higher education, they should also have access to courses in high demand, such as Law, Dentistry and Medicine. In the past, the 
demand from more capable students from low socio-economic areas declined due to raising HECS fees and the move from universities to offer full-fee paying places for domestic students. However, in 2009, the Rudd government phased out full-fee paying places for domestic students based on equity grounds despite the impact it would have on the revenue for universities. With relatively low government contributions for Commonwealth supported places in Law and the potential to earn high revenue for degrees in areas such as Law, Dentistry, and Medicine, universities have decided to offer graduate-entry degrees in these fields. Melbourne University was the first to introduce graduate-entry degrees in Australia; therefore, this approach taken by universities is known as adopting the Melbourne Model. The Melbourne Model requires students to complete a generalist degree, such as an Arts or Commerce degree, before enrolling into graduate-entry degrees such as Law, Dentistry or Medicine. According to Schwab (2009), universities, such as Melbourne University, argued that this would provide students with greater choice and a better quality education. Conversely, if disciplines such as Law, Dentistry or Medicine are removed from the list of undergraduate courses offered to students, this would provide less choice for students, not more. One, then, has to question the aim of the Melbourne Model and whether it is about improving the quality of education or rather a method to increase university revenue. Universities are able to charge full fees for half of the places they offer to domestic students in post-graduate programs, whereas all undergraduate places for domestic students must be Commonwealth supported places. This means that not only would the fees for these full-fee paying places be higher than for comparable undergraduate Commonwealth supported places, but also for half of the students these fees would be required to be paid up front. For example, a student who enrolled in a combined Arts/Law degree in 2010 would incur a HECS debt of $\$ 45,000$ for their five-year program, whereas a student who enrolled in a Juris Doctor at Melbourne University would pay $\$ 99,466$ for their graduate-entry degree in addition to the HECS fees they incurred for their generalist degree (Melbourne University, 2011). This means that students who do not have the financial capacity to pay the fees up front would have to take the risk and study a generalist degree in the hope that they achieve a government-supported place in the graduate-entry program. Even students who receive a government-supported FEE-HELP place need to be aware that the current limit, which is $\$ 85,062$, may not cover the entire cost of the graduate-entry program, such as the three-year Juris Doctor at Melbourne University. Not only will students pay more to study these degrees, the overall opportunity cost for these students will increase. For example, a student studying under the Melbourne Model will take a minimum of six years to become a lawyer, whereas it only took five years under an undergraduate program. This means that students will lose a minimum of an extra year of potential earnings while studying.

Table 3: University Applicants by Field of Education and SES Status - 2009

\begin{tabular}{|c|c|c|c|c|}
\hline \multirow[b]{2}{*}{ Field of Education } & \multicolumn{2}{|c|}{ All Low SES Applicants } & \multicolumn{2}{|c|}{ All High SES Applicants } \\
\hline & $\begin{array}{c}\text { Number of } \\
\text { Applications }\end{array}$ & $\begin{array}{c}\text { Proportion of } \\
\text { Applicants }\end{array}$ & $\begin{array}{c}\text { Number of } \\
\text { Applications }\end{array}$ & $\begin{array}{c}\text { Proportion of } \\
\text { Applicants }\end{array}$ \\
\hline Natural and Physical Sciences & 3,025 & $7 \%$ & 5,495 & $7 \%$ \\
\hline Information Technology & 1,344 & $3 \%$ & 1,733 & $2 \%$ \\
\hline Engineering and Related Technologies & 3,211 & $7 \%$ & 4,493 & $6 \%$ \\
\hline Architecture and Building & 1,221 & $3 \%$ & 3,371 & $4 \%$ \\
\hline Agriculture, Environmental and Related Studies & 874 & $2 \%$ & 1,208 & $2 \%$ \\
\hline Health & 10,911 & $24 \%$ & 16,452 & $21 \%$ \\
\hline Medical Studies & 1,043 & $2 \%$ & 4,656 & $6 \%$ \\
\hline Nursing & 4,672 & $10 \%$ & 3,670 & $5 \%$ \\
\hline Dental Studies & 491 & $1 \%$ & 1,262 & $2 \%$ \\
\hline Veterinary Studies & 432 & $1 \%$ & 842 & $1 \%$ \\
\hline Education & 5,723 & $13 \%$ & 4,273 & $5 \%$ \\
\hline Teacher Education & 5,466 & $12 \%$ & 4,097 & $5 \%$ \\
\hline Management and Commerce & 6,000 & $13 \%$ & 11,956 & $15 \%$ \\
\hline Society and Culture & 9,096 & $20 \%$ & 19,966 & $25 \%$ \\
\hline Law & 1,715 & $4 \%$ & 5,260 & $7 \%$ \\
\hline Creative Arts & 3,613 & $8 \%$ & 9,746 & $12 \%$ \\
\hline Food, Hospitality and Personal Services & 1 & $0 \%$ & 2 & $0 \%$ \\
\hline Mixed Field Programs & 9 & $0 \%$ & 2 & $0 \%$ \\
\hline Total & 45,028 & $100 \%$ & 78,697 & $100 \%$ \\
\hline
\end{tabular}

Source: DEEWR (2010) 
These developments will severely disadvantage low SES students. Table 3 shows that low SES applicants are already underrepresented in disciplines such as Medicine, Dentistry and Law. It is not that they do not have an interest in the area of health, as the proportion of low SES applicants studying Nursing is double that of high SES applicants. However, applicants from high SES areas are more likely to apply to study in the high income earning disciplines compared to the low SES students. As a result of the Melbourne Model, the increased cost of studying these discipline areas will further reduce the opportunities for those from low SES backgrounds.

Another issue to consider is whether the target of 20 percent of higher education enrolments at undergraduate level are from low socio-economic status backgrounds is achievable. Increasing the number of students accepted into university will not, in itself, increase the proportion of students attending and graduating from university from low SES backgrounds. There is no evidence to suggest that lowering entry scores will increase the proportion of low SES students commencing university studies. On the contrary, the Australian Catholic University actually had a decline in the proportion of commencing students from low SES backgrounds (from 14.5 percent to 12.6 percent) when they increased their over-quota enrolments between 2008 and 2010. In the period 2008 to 2011, the numbers of high SES-commencing students at the Australian Catholic University increased by 46 percent while the numbers of low SES-commencing students rose by only 24 percent (ACU, 2011).

The impact of higher attrition rates and lower income premiums as a result of increased numbers of university students is also likely to have a greater effect on discouraging students from low SES backgrounds because of the risk and subsequent HECS debt than students from higher SES backgrounds. This would also make the achievement of such a target more difficult.

\section{CONCLUSION}

This paper raises some serious concerns in regard to the implications of a 'demand-driven' higher education policy and the feasibility of a number of key recommendations of the Bradley Review. There is already evidence that giving greater autonomy to universities to make decisions about student numbers and how courses are operated will not be in the interest of access to or the quality of education. Instead, they will be based on how universities can maximise the funds they receive for their students. The increase in student numbers and lower university entry scores in a number of universities are likely to lead to increased attrition rates of students and a lower proportion of completions at considerable cost to the students and the Australian government. At the same time, there has also been a decline in the proportion of students of higher ability accepting offers to study at university. McInnis and Hartley (2002) have shown that there is a positive relationship between a student's university entrance score and grade point average that they achieve at university. A continuation of these trends would most likely produce lower quality graduates. This study suggests that access to Australia's higher education system, especially in areas such as Law, Dentistry, and Medicine, is moving further toward a system based on one's ability to pay rather than a student's academic ability. In addition, the government's target of 40 percent of all 25 to 34-year olds attaining a bachelor degree or above by 2020 is likely to be in conflict with targets to increase TAFE and vocational skill qualification levels. A balance between university qualifications and TAFE and vocational skillbased qualifications is essential for Australia's future growth and satisfying labour market needs.

The target of 20 percent of higher education enrolments at the undergraduate level being from low socioeconomic status backgrounds is not likely to be achieved under current arrangements. This paper has shown that letting more students into university, by itself, will not increase the proportion of low SES students. The way to raise the proportion of low SES students is to increase the number and level of scholarships and student support allowances. These need to be made available to students as early as possible so that university study will become a viable option, especially for the most disadvantaged groups.

This paper recommends that quotas should remain on university courses and that they should be adjusted to reflect labour market needs. It also recommends that the HECS charges should be substantially reduced to be more in line with the average contribution made by university students in other OECD nations (Stokes and Wright, 2010). These recommendations would most likely encourage more capable students to enter university and a greater proportion of students from low socio-economic backgrounds to pursue higher education. This, in turn, would increase Australia's human capital and boost Australia's productivity and international competitiveness. 


\section{AUTHOR INFORMATION}

Dr Anthony Stokes is a senior lecturer in economics at the Australian Catholic University, Sydney, Australia. He has written extensively in areas of school and higher education policy and has been awarded a number of teaching awards and citations. E-mail: tony.stokes@acu.edu.au (Corresponding author)

Dr Sarah Wright is a lecturer in economics at the Australian Catholic University, Sydney, Australia. She has written extensively in areas of higher education policy and has been awarded a number of teaching awards and citations. E-mail: sarah.wright@acu.edu.au

\section{REFERENCES}

1. Australian Catholic University (ACU). (2012). Statistical digest. Retrieved from: http://www.acu.edu.au/staff/our_university/statistics/statistics_for_acu/

2. Australian Vice-Chancellor's Committee. (AVCC). (2006). Report on applications for undergraduate university courses. Canberra, Australian Vice-Chancellor's Committee. Retrieved from: http://www.universitiesaustralia.edu.au/documents/publications/stats/unmet/Unmet_Demand_Report_2006 .pdf

3. Australian Vice-Chancellor's Committee. (AVCC). (2010). Undergraduate Applications, Offers and Acceptances Report 2009. Canberra, Australian Vice-Chancellor's Committee. Retrieved from: http://www.deewr.gov.au/HigherEducation/Publications/HEReports/Pages/UndergradAppOffersandAccept Reports.aspx

4. Becker, G. S. (1975). Human capital. New York, National Bureau of Economic Research.

5. Borg, J. (2006). An investigation of participation in post-school education of students from different socioeconomic backgrounds. Hons thesis (unpublished). Strathfield, Australian Catholic University.

6. Borland, J. (2002). New estimates of the private rate of return to university education in Australia. Melbourne, Department of Economics, University of Melbourne.

7. Bradley, D. et al. (2008). Review of Australian Higher Education Final Report. Canberra, Australian Government.

8. Council of Australian Governments (COAG). (2009). National Agreement for Skills and Workforce Development. Canberra, Australian Government. Retrieved from: http://www.federalfinancialrelations.gov.au/content/national agreements/downloads/IGA FFR ScheduleF _NSWD_National_Agreement.pdf

9. Department of Education, Employment and Workplace Relations (DEEWR). (2010). Higher Education Statistics. Canberra, Department of Education, Employment and Workplace Relations. Retrieved from: http://www.deewr.gov.au/HigherEducation/Publications/HEStatistics/Publications/Pages/Home.aspx

10. Department of Education, Employment and Workplace Relations (DEEWR). Skill Shortage ListAustralia 2010. Canberra, Department of Education, Employment and Workplace Relations. Viewed: $7^{\text {th }}$ March 2012, http://www.deewr.gov.au/Employment/LMI/SkillShortages/Pages/SkillShortageLists.aspx

11. Graduate Careers Australia. (2010). GradStats No 15 December 2010. Retrieved from: http://www.graduatecareers.com.au/ucm/groups/content/documents/document/gca001543.pdf

12. James, R. (2002). 'How student perspectives challenge conventional market theory'. Melbourne, Centre for the Study of Higher Education, University of Melbourne. Retrieved from: http://www.cshe.unimelb.edu.au/downloads/Marketing_Conf_Sydney_2002.pdf.

13. Lui, H. and Suen, W. (2005). The shrinking earnings premium for university graduates in Hong Kong: The effect of quantity or quality? Contemporary Economic Policy, vol. 23 no. 2, pp. 242-254.

14. McInnis, C. and Hartley, R. (2002). Managing study and work. The impact of full time study and paid work on the undergraduate experience in Australian universities. Canberra, Department of Education, Science and Training. Retrieved from: http://www.dest.gov.au/highered/eippubs/eip02_6/eip02_6.pdf.

15. McMillan, J. (2005). Course change and attrition from Higher Education (LSAY Research Report No. 39). Melbourne, ACER.

16. Melbourne University. (2011). Melbourne Law School. The Melbourne JD. Melbourne, The University of Melbourne. Retrieved from: http://www.cshe.unimelb.edu.au/downloads/Marketing_Conf_Sydney_2002.pdf 
17. Organisation for Economic Cooperation and Development (OECD). (2010) Education at a glance 2010. Paris, OECD. Retrieved from: http://www.oecd.org/document/52/0,3746,en_2649_39263238_45897844_1_1_1_1,00.html

18. Schwab, A. (2009). 'Melbourne muddle: Elite students turning away from law in droves'. Crikey. $13^{\text {th }}$ November. Retrieved from: http://www.crikey.com.au/2009/11/13/melbourne-muddle-elite-studentsturning-away-from-law-in-droves/

19. Stokes, A. and Wright, S. (2010). Are university students paying too much for their education in Australia?' Journal of Australian Political Economy, vol. 65 no. 2 pp. 5-27.

20. University Admission Centre (UAC). (2008). UAC Guide 2008. Sydney, University Admission Centre.

21. University Admission Centre (UAC). (2011). Cut-offs for main round offers 2011. Sydney, University Admission Centre. Retrieved from: http://www.uac.edu.au/documents/atar/2011_coffs main.pdf

22. University World News. (2010). 'New Zealand: Enrolment restrictions to be fast-tracked'. $16^{\text {th }}$ May. University World News. Retrieved from:

http://www.universityworldnews.com/article.php?story=20100514202918656\&mode=print

23. Wei, H. (2010). Measuring economic returns to post-school education in Australia. Canberra, ABS. Retrieved from: http://www.ausstats.abs.gov.au/Ausstats/subscriber.nsf/0/FFF12BBAB5051BFFCA25778C001F6903/\$Fil e/1351055032 aug\%202010.pdf

24. Wright, S. J. (2005). The impact of changes in HECS on students from low socio-economic backgrounds. Sydney, Greenacre Educational Publications.

25. Wright, S. J. (2008). An investigation into the equity and efficiency of Australia's higher education system. Sydney, Greenacre Educational Publications. 


\section{NOTES}

